\title{
PROVINCIAL ROYALTIES AND CREDITS
}

\author{
BRYAN R. EMES*
}

\begin{abstract}
This paper is current to May 1988. It revie's's the fiscal regimes under which royalies and production-related taxes are imposed in Alberta. Saskatchewan and British Columbia. Its focus is on recent changes to gas royallies, particularly in Alberta and Saskatche'u'an. where significant revisions have recently laken place. The Alberta Royalty Tax Credit is also reviewed.
\end{abstract}

\section{INTRODUCTION}

Section $92 \mathrm{~A}$ of the Constitution Act, 1867,' as amended by the Constitution Act, $1982,{ }^{2}$ provides that the Legislature of each Province may exclusively make laws in relation to the raising of money by any mode or system of taxation in respect of nonrenewable natural resources in the Province and primary production therefrom. "Primary production" is defined to include production of a resource if it is in the form in which it exists upon its recovery or severance from its natural state. ${ }^{3}$

Pursuant to these powers, the Provinces of Alberta, Saskatchewan and British Columbia all reserved and derived substantial revenue from royalties imposed with respect to petroleum and natural gas produced from Crown lands. In addition, the Provinces have imposed taxes on freehold lands.

In exercising its power to reserve a royalty or to tax production, a government can take a number of factors into account. A primary concern from the standpoint of the province may well be the generation of a required stream of revenue. Subject to this overall revenue requirement, it is generally desirable to structure a royalty such that it does not adversely affect the level of resource exploitation or the rate at which resources are brought on stream. To borrow an economist's phrase, to avoid inhibition of the exploitation of a resource, a royalty should be paid only out of "economic rent" - that is, over and above the economic return accruing to a scarce resource over the return sufficient to attract it into use. ${ }^{+}$In addition, a province may wish to structure the royalty such that it promotes conservation of resources. ${ }^{5}$ For example, tertiary production methods which make possible production of reserves which might otherwise not be produced, might be encouraged by a low royalty rate.

Where resource activity is an important part of the economy, the royalty rates and structure may be used to promote goals of the government related to stabilization of the economy and economic growth and development. Royalty structure and related programs might also be used as an instrument of social policy to encourage development of certain segments of the economy, such as small or locally-based producers.

Ideally, as with a tax, a royalty system should be relatively straightforward to understand and to administer. In addition, it should be equitable, treating parties in similar circumstances similarly, while differentiating between persons in different

* Solicitor, Bull, Housser and Tupper. Vancouver, British Columbia.

1. Originally, the British North America Act, 1867.

2. Constitution Act, 1982 as enacted by Canada Act 1982 (U.K.), c.11.

3. Id. sub-s. 92.A(5) and Sixth Schedule.

4. This required return will vary from industry to industry and generally will be difficult to predict where uncertainty is a primary characteristic in assessing a particular venture.

5. Scott, A.W., Natural Resources: The Economics of Conservation (University of Toronto Press. Toronto, 1955). 
circumstances fairly. ${ }^{6}$ Many of these criteria conflict and doubtless some are entirely disregarded in concept or substance when a system is devised or amended. However, many of these are also reflected by design or otherwise in the systems devised by the provinces and in changes to those systems.

In the past two years, each of the provinces has made substantial revisions to its royalty systems, primarily with respect to the royalties reserved or excepted with respect to natural gas, but also in respect of oil as well. The purpose of this paper is to review the petroleum and natural gas royalty structures of Alberta and Saskatchewan and, to a lesser extent, British Columbia and to discuss these revisions. The royalty structures are in each case complex and establish different regimes for old oil, new oil, old gas, new gas, enhanced recovery oil, liquids and for other classifications of oil and gas.

Also briefly discussed is the Alberta Royalty Tax Credit ("ARTC") program which provides refundable tax credits to producers based on, in effect, their Crown royalties paid. The ARTC program effectively reduces the Crown royalty rate for smaller producers by about three-quarters of royalties otherwise payable but has only a minor or no effect on the average and marginal royalty rates paid by larger producers. It thus represents an interesting use of the royalty system and related fiscal measures to effect a particular policy goal.

There are limitations to the scope of this paper. Freehold mineral taxation, which is worthy of examination and imposed in all three provinces, is not discussed. In addition, there is no discussion of "royalty holidays" sometimes available in respect of exploratory and other wells. Nor is there a discussion of the bonus system by which the initial right to exploit an area is acquired. These, space permitting, would ideally be considered and compared between provinces as further pieces in the overall picture of how the provinces exercise their rights to resource ownership and management.

\section{ALBERTA}

\section{A. GAS ROYALTIES}

\section{Royalty Structure}

Gas royalties in Alberta are imposed, inter alia, pursuant to the Mines and Minerals Act and the Natural Gas Royalty Regulations. ${ }^{7}$ The Mines and Minerals Act reserves to the Crown in right of Alberta a royalty, ${ }^{8}$ which is to be prescribed by the Lieutenant Governor in Council. ${ }^{9}$

The royalty reserved with respect to natural gas in Alberta depends on whether the gas is "new gas". In general, new gas is gas produced from pools that were initially discovered on or after January 1, 1974, gas from pools where no gas was sold or

6. Due. J.F. and Friedlander, A.F.. Gorernment Finance: Economics of the Public Sector (Richard D. Irwin. 7th Ed., 1981) 234-237. Because it is imposed by virtue of the Crown's ownership of the resource, a royalty is not necessarily a tax. However, the attributes of a "good" tax should probably apply in respect of Crown charges generally.

7. The Mines and Minerals Act, R.S.A. 1980. c. M-15 as am.; Natural Gas Royalty Regulations, Alta. Reg. 16/74, as am. Alta. Regs. 19/74, 152/75, 242/76. 337/78, 244/79, 444/81, 183/82, 216/82, 322/ $82,461 / 82,293 / 83,164 / 84,148 / 85,156 / 85,217 / 85,354 / 85,194 / 85,268 / 86$ and $365 / 86$.

8. Id., Mines and Minerals Act s. 34 .

9. Id. s. 35 . 
consumed for some useful purpose prior to January 1, 1974 and certain other classifications of gas. ${ }^{10}$ Other gas, generally referred to as "old gas", is generally gas discovered before December 31, 1973.

In general, the royalty reserved with respect to Alberta gas is a percentage determined by reference to the price of gas. The basic royalty formula with respect to old gas is:

$$
\mathrm{R} \%=\frac{39050+40(\mathrm{~F}-1775)}{\mathrm{F}}
$$

where " $F$ " means the average selling price per thousand cubic metres $\left(\mathrm{m}^{3}\right)$ for the month of natural gas or residue gas and "R\%" means the Crown's royalty share expressed as a percentage of the natural gas or residue gas."

The royalty formula applies to gas selling at a price in excess of $\$ 17.75$ per thousand $\mathrm{m}^{3}$ (about $\$ 0.50$ per thousand cubic feet ["MCF"]), imposes a royalty which rises from 22 per cent (at a price of $\$ 17.75$ per thousand $\mathrm{m}^{3}$ ) to a theoretical maximum of 40 per cent as the price increases beyond $\$ 17.75 .^{12}$

For old gas sold below the price of $\$ 17.75$ per thousand $\mathrm{m}^{3}$, the royalty payable is $22 \%$ of the value of the gas. ${ }^{13}$

There are two formulae for new gas, in the same format, with their application depending on the price of gas. For an average selling price equal to $\$ 17.75$ per thousand $\mathrm{m}^{3}$ but less than $\$ 71.00$ per thousand $\mathrm{m}^{3}$ (that is, from $\$ 0.50$ per MCF to $\$ 2.00$ per MCF), the following royalty formula applies:

$$
\mathrm{R} \%=\frac{39050+27(\mathrm{~F}-1775)}{\mathrm{F}}
$$

where "R\%" and " $F$ " are defined as above. ${ }^{14}$ This produces a royalty ranging from 22 per cent (with prices of $\$ 17.75$ per thousand $\mathrm{m}^{3}$ ) to 25.75 per cent (at a price of $\$ 71.00$ per thousand $\mathrm{m}^{3}$ ).

10. Supia n. 7. Natural Gas Royalty Regulations at sub-s. 4(3.1) of Schedule 1. New gas is also defined to include (in paras. 4(3.1)(c), (d), (e) and (f) of Schedule 1, respectively):

(c) natural gas which is obtained from the gas cap of a pool initially discovered before January 1 . 1974 (excluding associated gas) but only if none of the natural gas so obtained and none of the residue gas or other products derived therefrom were sold or consumed for some useful purpose before January 1, 1974;

(d) natural gas obtained from a pool initially discovered before January 1. 1974, but only if obtained from a production spacing unit or the area of a unit operation located wholly outside the area that has been or is designated for the pool under the Oil and Gas Conservation Act on the basis of a well or wells drilled into the pool before January 1, 1974:

(e) natural gas obtained from a well in a block established in a natural gas pool initially discovered before January 1,1974 , but only if the well is located outside the area that has been or is designated for the pool under the Oil and Gas Conservation Act on the basis of a well or wells drilled into the pool before January 1. 1974:

(f) natural gas obtained as a result of the operation of a scheme for the conservation of natural gas produced unavoidably with crude oil. but only if none of the natural gats so obtained and none of the residue gas or other products derived therefrom were sold or consumed for some useful purpose before January 1, 1974.

11. Id. s. 3 .

12. The royalty rate asymbolically approaches 40 per cent as the price factor, " $F$ ", approaches infinity.

13. Supra n. 10. s. 2 of Schedule 1.

14. Id. sub-s. 4(4). 
For new gas selling at a price in excess of $\$ 71.00$ per thousand $\mathrm{m}^{3}$, the royalty formula is:

$$
\mathrm{R} \%=\frac{182825+30(\mathrm{~F}-7100)}{\mathrm{F}}
$$

where "R\%" and "F" are again defined as above. ${ }^{15}$ This royalty formula, again in the same format, results in a royalty rising at a decreasing rate from 25.75 per cent to 30 per cent as the price of gas rises.

In all three cases, the royalty rate is somewhat price sensitive: as the gas price increases, both the royalty rate and the price to which the rate is applied will increase, with the effect that the dollar value royalty increases by a larger percentage than the price of gas. As a result, when prices rise, the Province will obtain a larger share of the value of production and a larger share of economic rent associated therewith. Similarly, with decline in price, royalties reserved will fall at a faster rate than revenue.

A reduced royalty applies for low productivity wells. When production from a well is less than $16,900 \mathrm{~m}^{3}$ per day, the royalty rate is reduced by use of the following formula:

$$
R \%=R_{c}-\frac{\left(R_{c}-5\right)(16.9-P)^{2}}{(16.9)^{2}}
$$

where " $R_{c}$ " is the royalty, expressed as a percentage, that would be applicable to the natural gas or residue gas, if the royalty was determined in accordance with the other royalty formulae, and "P" is the average daily production for the well for the month expressed in thousands of cubic metres. ${ }^{16}$ The effect of this formula is to increase the royalty chargeable from a minimum of $5 \%$ to the royalty rate as otherwise determined as production increases to $16,900 \mathrm{~m}^{3}$ per day.

Alberta allows a deduction in computing the net royalty payable in respect of the cost of processing natural gas. The "gas cost allowance" is a discretionary amount allowed by the Mines and Minerals Act and the Natural Gas Royalty Regulations. ${ }^{17}$ Its calculation is governed by a set of "guidelines" produced by the Department of Energy and Natural Resources. ${ }^{18}$

The gas cost allowance is determined for each producer at each processing facility, based on a formula (the "G-3") which effectively creates a deemed cost of service for processing gas using a variation of the Jumping Pound formula. The formula allows for operating costs, depreciation and a 15 per cent return on depreciated capital including a return in respect of working capital (based on operating costs). The share of plant costs (based on throughput volumes) which are attributable to gas produced from Crown lands is first determined; to that is applied the applicable royalty rate to derive the allowance. The amount of the allowance is used to reduce the amount of Crown royalty payable. ${ }^{19}$

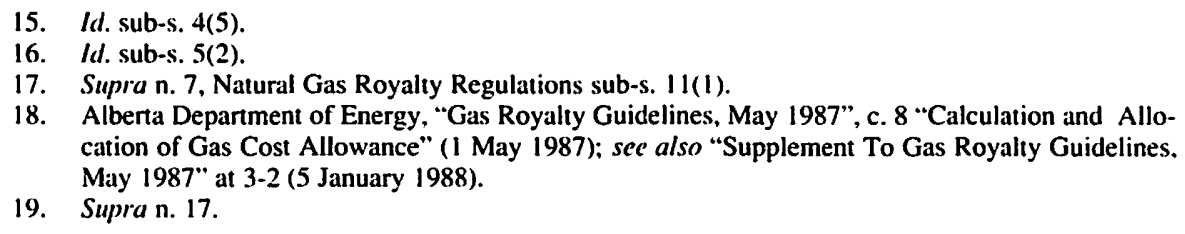

18. Alberta Department of Energy, "Gas Royalty Guidelines, May 1987", c. 8 "Calculation and Allocation of Gas Cost Allowance" (I May 1987); sec also "Supplement To Gas Royalty Guidelines. May 1987" at 3-2 (5 January 1988).

19. Supra n. 17. 


\title{
2. Changes to Gas Royalty Rates
}

In part as a result of the Western Accord, "An Agreement made between the Governments of Canada, Alberta, Saskatchewan and British Columbia on Oil and Gas Pricing and Taxation",20 and in part as a result of falling oil and gas prices, Alberta phased in a reduction of its oil and gas royalty rates to their present level. The end of the National Energy Program resulted in the phase-out of the Petroleum and Gas Revenue Tax ("PGRT") imposed by the Government of Canada on oil and gas production and of exploration and development grant programs established by the Government of Canada (the Petroleum Incentive Program or "PIP") and the Government of Alberta (the Alberta Petroleum Incentive Program or "APIP”). The PGRT was designed to tax oil and gas production revenues; the PIP and APIP programs were designed to provide grants to assist exploration and development within Canada and Alberta, respectively.

Clause 10 of the Western Accord ${ }^{21}$ provides that:

\begin{abstract}
The parties to this understanding reserve the right, as resource owners, to establish and adjust from time to time their royalty and incentive systems for the development of oil and gas within their respective jurisdictions. Such adjustments, including changes to APIP. shall be consistent with the objective expressed above of flowing through to the industry the net benefits of the fiscal and price decontrol changes agreed to herein.
\end{abstract}

As of July 9, 1985, the theoretical maximum royalty rate for old gas was reduced from 45 per cent to 43.5 per cent and the top possible royalty rate for new gas from 35 per cent to 33.5 per cent. ${ }^{22}$

In response to falling oil prices, a further reduction in the 43.5 and 33.5 per cent was implemented on July $23,1986 .^{23}$ On November 20,1986 , the maximum royalty rates were further reduced to 40 per cent for old gas and 30 and 27 per cent for new gas, as discussed above. ${ }^{24}$ The royalty rates applying at relatively low prices did not fall in the same proportion as rates applicable where prices were higher. For example, with an average selling price (" $F$ " value) of $\$ 20.00$ per thousand $\mathrm{m}^{3}$, the royalty formula in place in 1985 would have resulted in a royalty rate of about 24.6 per cent. Under the revised formulae, the rate would be marginally lower, 24.0 per cent. At the same price, royalty rates for new gas would be reduced from 23.5 per cent to 22.6 per cent. At higher prices, however, rate reductions were more significant: the royalty rate at $\$ 71.00$ per thousand $\mathrm{m}^{3}$ fell from 31.8 per cent to 27 per cent, about 15 per cent of the royalty.

The manner in which royalty rates are determined was also altered effective January 1, 1988, by changing the method of calculation of the price (currently, the "F" factor) used in determining the royalty rate. Apparently, certain recent gas sales have been at prices which the Government of Alberta believes is less than the appropriate value. When gas is sold at a relatively low price, both the royalty rate and, more importantly, the price to which the royalty rate is applied, are reduced. As a result, the Province of Alberta announced that it was considering two initiatives to

20. "An Agreement Among the Governments of Canada, Alberta, British Columbia and Saskatchewan on Oil and Gas Pricing and Taxation" (27 March 1985) (referred to herein as "The Western Accord").

21. Id.

22. Alta. Regs. $216 / 82$ and $217 / 85$.

23. Alta. Reg. 268/86.

24. Alta. Reg. $365 / 86$. 
ensure that the royalty which it achieved with respect to its gas would not be unduly reduced by virtue of deeply discounted gas prices. ${ }^{25}$

The first of these initiatives is the introduction of the average market price ("AMP") as a substitute for the "F" factor in calculation of the royalty rate. Prior to any month, the province will now publish the AMP based on recent sales of gas which is used in the royalty formulae to calculate its share. ${ }^{26}$

In addition to determining the royalty rate by the use of the AMP, in certain circumstances, the price to which that rate is applied will depend upon the AMP. Should the price obtained by a particular producer be less than $80 \%$ of the AMP, he will be deemed to have received $80 \%$ of the AMP on the sales for the purpose of determining his royalty. ${ }^{27}$ Thus, if the price of gas obtained by the producer is $\$ 50.00$ per thousand $\mathrm{m}^{3}$ and the AMP is $\$ 70.00$, then the producer will be deemed to have obtained $\$ 56.00$ per thousand $\mathrm{m}^{3}$, being $80 \%$ of the AMP. This provision may reduce incentives to sell gas at a deep discount to the market; after a certain point, the producer will bear the entire burden of a further price discount even though the price he obtains will be with respect to both his own gas and the Crown gas. ${ }^{28}$

The second major initiative proposed by Alberta with respect to natural gas royalties was to be the imposition of an average corporate price for non-arm's length sales. It appears that the corporate average price ("CAP") was proposed to avoid royalty minimization through price manipulation. ${ }^{29}$ The possible need for the Province's proposed action was foreseen, at least in part, in the Agreement among the Governments of Canada, Alberta, British Columbia and Saskatchewan on Natural Gas Markets and Prices. ${ }^{30}$ Clause 24 of that Agreement ${ }^{31}$ provides that:

\begin{abstract}
Non-arm's length sales of natural gas between producers and shippers, between producers and distributors, or between producers and consumers shall be subject to appropriate provincial legislation for purposes of determining and collecting royalty or mineral tax revenues payable to the respective provincial Crown.
\end{abstract}

The CAP was to be determined by calculation of the prices received from companies in third party arm's length sales. ${ }^{32}$ Any price less than $80 \%$ of the AMP would be adjusted to the $80 \%$ level. Non-arm's length sales (such as sales to affiliated companies) would be ignored as would "swaps and exchanges". ${ }^{33}$ Where gas was sold other than in arm's length circumstances, the corporate average price would be used to determine the amount to which the royalty rate would be applied. As a result,

25. Alberta Department of Energy, "Natural Gas Royalty Review, 28 October 1987" (referred to herein as "Royalty Review"); Govermment of Alberta, "News Release" (3 December 1987); Alberta Department of Energy. "Information Letter 87-35: Changes to the Natural Gas Royalty System" (undated).

26. Id. "Information Letter 87-35".

27. Id.

28. There is at least a theoretical possibility that under this formula the producer's liability for Crown royalty could exceed the amount which he receives from the sale of gas. For example. if the AMP were $\$ 71$ per thousand $\mathrm{m}^{3}$, the royalty rate imposed would be 35.5 per cent for new gas. The AMP under such circumstances would be $\$ 56.80$ and every producer will be considered to have obtained at least that price. The related royalty will be at least $\$ 20.16$, irrespective of the price actually achieved (unless it exceeds 80 per cent of AMP). In the unlikely event that the price a producer obtained was less than $\$ 20.16$, the Crown royalty would exceed his entire proceeds of sale.

29. Supra n. 25, "Royalty Review".

30. "Agreement Among the Governments of Canada, Alberta, British Columbia and Saskatclsewan on Natural Gas Markets and Prices" (31 October 1985) reproduced in Canada Energy Law Service, Hunt et al. Editors (Canadian Institute of Resources Law, Richard DeBoo Publishers) Vol. 3 at 30 . 1803 et seq.

31. Id. cl. 24

32. Supra n. 25. "Royalty Review".

33. Id. 
sales to consuming affiliates, for example, at less than fair market value or less than the corporate average price will not result in reduced royalty rates.

The petroleum industry has offered substantial criticism with respect to the concept of the corporate average price, but more particularly objected to the administrative inconvenience which the imposition of this price would cause. The Province has delayed introduction of the CAP and its use might never be implemented. ${ }^{34}$

Alberta is also proposing to change the gas cost allowance to reflect use of the AMP. It is also proposed that by mid-1988, calculation of the gas cost allowance be on a "functional plant" basis, much as is done in Saskatchewan, with special rates rather than actual costs determining the amount of the allowance. ${ }^{35}$

\section{B. OIL ROYALTIES}

The rate at which crude oil royalties are charged in Alberta depends upon whether oil is "new oil" or "old oil". In general, crude oil will be classified as new oil if it is produced from a well in a "new oil entity" or is a specified portion of the crude oil produced from a well in a "coexistent new oil entity". The status of a production entity as a "new oil entity", "coexistent new oil entity", or otherwise, is determined by the Minister of Energy. ${ }^{36}$ In general, new oil entities include "production entities" in a pool determined by the Minister to have been discovered on or after April 1, 1974 on the basis of wells with finished drilling dates occurring on or after that date. ${ }^{37}$ In addition, new oil will include oil produced from production entities in extensions of a pool if the extension is (in the Minister's opinion) attributable to wells with finished drilling dates occurring on or after April 1, 1974 where no part of the production entity is located within the portion of the pool located outside of the extension. ${ }^{38}$ In addition, certain other oil will be classed as new oil, including oil from entities which had ceased production for at least three years (and which recommenced production after May 1, 1980), and certain other oil. ${ }^{39}$ The "coexistent new entity" will arise in a number of circumstances where an extension to a pool is only part of the production entity. ${ }^{40}$ The Regulations contain rules for determining the portion of oil from the coexistent new oil entity which is new oil.

The royalty charged with respect to old oil depends upon whether the "old oil par price" for the month exceeds the "select price of crude oil" for the month. The old oil par price is prescribed by the Minister for the month; ${ }^{41}$ the select price of crude oil is determined by the Lieutenant Governor in Council. ${ }^{42}$ It is usually set at $\$ 40.90$ per $\mathrm{m}^{3} .{ }^{43}$

34. Discussions with officials of the Alberta Department of Energy in the Spring of 1988 .

35. Supra n. 25, "Royalty Review".

36. Petroleum Royalty Regulations, Alta Reg 93/74, as am. Alta. Regs. 251/74, 243/76, 9/77, $249 / 79$, $268 / 79,162 / 80,34 / 82,39 / 82,182 / 82,320 / 82,462 / 82,291 / 83,415 / 83,13 / 84,167 / 84,154 / 85.216 /$ 85 . $355 / 85,395 / 85$ and $380 / 86$.

37. Id. para. $2.1(3)(\mathrm{a})$.

38. Id. para. $3.1(3)(\mathrm{b})$.

39. Id. para. $2.1(3)(\mathrm{c})$.

40. Id. paras. $2.1(3)$ (d) to (i).

41. Id. para. $2(1)(a)$.

42. Id. para. I.I(1)(c) and sub-s. I.I(2).

43. Alberta Department of Energy, "Information Letter 87-36: Crude Oil Par Price, Select Price and Royalty Factors Natural Gas Average Market Price for the Month of January, 1988": "Information Letter 88-4" (for February 1988); "Information Letter 88-5" (for March 1988); "Information Letter 88-10" (for April 1988). 
Where the old oil par price is not greater than the select price of crude oil for the month, the royalty in respect of old oil is established by Schedule $A$ to the Regulations. ${ }^{44}$ This royalty is production sensitive: where monthly production is under $190.7 \mathrm{~m}^{3}$, the royalty for the month is the square of the number of cubic metres produced divided by the number 1271.28 . For example, where $100 \mathrm{~m}^{3}$ are produced in the month, the royalty (taken in kind) will be in the order of $7.9 \mathrm{~m}^{3}(7.9$ per cent of oil produced). For production at the cut-off point for the application of this formula, $190.7 \mathrm{~m}^{3}$, the royalty will be $28.6 \mathrm{~m}^{3}$, some 15 per cent of oil produced. For production in excess of $190.7 \mathrm{~m}^{3}$, the incremental royalty is 25 per cent of production. For example, where $290.7 \mathrm{~m}^{3}$ is produced (100 more than the 190.7 limit for the other formula), the royalty will be $53.6 \mathrm{~m}^{3}$ ( $25 \mathrm{~m}^{3}$ more than at the cut-off point $) .{ }^{45}$

Where, as is normally the case, the old oil par price exceeds the select price for the month, a different formula is in force. Because the select price is generally far lower than the old oil par price, it is this formula which is used:

$$
R=S+k S \frac{(A-B)}{A}
$$

where " $R$ " is the royalty payable in cubic metres, " $S$ " is the number of cubic metres determined in accordance with the table in Schedule $B$ to the Regulations, " $k$ " is the old oil royalty factor for the month, " $A$ " is the old oil par price for the month and " $B$ " is the select price of crude oil for the month. ${ }^{46}$ The " $S$ " factor is effectively the royalty charged where the select price exceeds the old oil par price. The balance of the formula merely adjusts that royalty to make it slightly price sensitive and, in fact, the formula can be recast as a simple price sensitive multiplier of that rate. The effect of this price adjustment can be demonstrated with current factors.

For February, 1988, for example, when "k" was set at 0.846154 , "A" at $\$ 130.00$ per $\mathrm{m}^{3}$, and "B" at $\$ 40.90$, the royalty rate for a well producing $400 \mathrm{~m}^{3}$ per month would have been $32.0 \%$. The royalty rate, "R", effectively became " $S$ " multiplied by 1.579941 . On March 30,1988 , the par price fell to $\$ 122.00 \mathrm{per}^{3}$. "R" became "S" multiplied by $1.562484 .{ }^{47}$ The royalty for a well producing $400 \mathrm{~m}^{3}$ per month would have been 31.6 per cent. Were prices to rise to $\$ 150 \mathrm{per}^{3}$, the royalty would rise to 32.7 per cent based on the same production. Were the par price to fall to $\$ 100$ per $\mathrm{m}^{3}$, the royalty rate for the same production would be 30.3 per cent. In each case, of course, the slightly-fluctuating royalty rate would be applied to oil which also fluctuated in value.

For new oil, the royalty rate applicable where the new oil par price exceeds the select price is determined by the following formula:

$$
R=S+y S \frac{(X-B)}{X}
$$

where " $R$ " is again the royalty payable in cubic metres, " $S$ " is determined as above, " $y$ " is the new royalty factor for the month, " $X$ " is the new oil par price and " $B$ " is the select price of new oil for the month ${ }^{48}$ (usually set at $\$ 40.90$ per m $\left.^{3}\right)^{49}$

44. Siupra n. 36, s. 1 .

45. Id. Schedule A.

46. Id.

47. Supra n. 43.

48. Supra n. 36. sub-s. 2(10).

49. Supra n. 43. 
Again, the effect of this formula is to determine a price sensitive formula which adjusts the volume-determined " $\mathrm{S}$ " factor. For April, 1988, this multiplier was determined to be 1.163632 (with par and select prices as above). For February, 1988, where par prices were higher, the multiplier was effectively determined to be 1.168710. Using a well producing $400 \mathrm{~m}^{3}$ per month, the royalty rates determined would be about 23.5 per cent to 23.6 per cent. ${ }^{50}$

While there is an attempt to make crude oil royalty rates price sensitive, within normal price fluctuations, there may be very small changes in the volume of Crown oil reserved where price fluctuations take place within the normal band.

\section{ALBERTA ROYALTY TAX CREDIT}

As noted above, the actual royalty reserved to the Crown may overstate a producer's overall liability to the Crown because of the refundable Alberta Royalty Tax Credit ("ARTC").

Section 26.1 of the Alberta Corporate Income Tax Act" (the "Alberta Act") provides that a corporation which has "Alberta Crown Royalty" in a taxation year is entitled to a royalty tax credit in certain circumstances. The amount of the credit available is limited to the lesser of: ${ }^{52}$

(a) a percentage specified in section 26.1(2) of the Alberta Act (the "specified percentage") of the Alberta Crown Royalty for the year; and

(b) the corporation's "maximum allowable credit" for the year, as computed in accordance with section 26.1(3) and (4) of the Alberta Act.

The term "Alberta Crown Royalty" is defined not as the corporation's royalty payments to the Province in the year, but rather is defined in terms of the Income Tax Act (Canada) (the "Federal Act") ${ }^{53}$ as the sum of: ${ }^{54}$

(a) any amount required to be included in computing the corporation's income for the year by virtue of paragraph 12(1)(o) of the Federal Act, and

(b) any amount in respect of which no deduction is allowed in computing the corporation's income for the year by virtue of paragraph $18(\mathrm{l})(\mathrm{m})$ of the Federal Act.

The basis of this definition and the origin of the credit lies in the dispute which arose in the early 1970's between Alberta and other producing provinces and the Government of Canada with respect to sharing of resource revenues. The increase in oil prices which occurred during that era was accompanied by increases in Crown royalty rates, which increases were made in an effort by Alberta to capture a greater share of the appreciation in the price of oil through increased royalties. As long as royalties were directly deductible in computing income, the Government of Canada would lose tax revenue with each increase in royalties. By increasing royalties, Alberta reduced producer incomes and their federal tax liability (current or deferred) to the Federal Government's detriment. Had higher royalties been charged to a taxable entity, the effect on the Federal tax revenue would have been neutral, albeit higher incomes were being taxed and greater tax revenues generated as a result of overall increases in production revenue.

50. Id.

51. R.S.A. 1980, c. A-17, as am. (referred to herein as "the Alberta Act").

52. Id. sub-s. 26.I(I).

53. Income Tax Act, S.C. 1970-71-72-73, c. 63, as am. (referred to herein as "the Federal Act").

54. Id. para. $26(1)(c)$. 
As of May 16, 1974, the Federal Act was amended to correct this perceived misdirection of producer incomes by enactment of paragraphs 12(l)(o) and $18(\mathrm{l})(\mathrm{m})$ of the Federal Act. In general terms, paragraph 12(l)(o) of the Federal Act includes in the income of a taxpayer amounts delivered in kind to the Crown in right of Canada or a province. ${ }^{55}$ Absent this provision, a royalty payable in kind would not generally form part of the income of the payer because the oil, once produced, would belong to the Crown in right of Alberta by virtue of its reservation of the same.

Paragraph 18(1)(m) of the Federal Act achieves the same end with respect to the royalties payable in money. It provides essentially that there may be no deduction in computing income in respect of any amount paid as an oil and gas royalty to the Crown in right of Canada or a province. ${ }^{56}$

As a substitute for the cost deduction and compensation for the inclusion in income, paragraph $20(1)(\mathrm{v} .1)$ of the Federal Act and Part XII of the Income Tax Regulations allows deduction of a "resource allowance" which is effectively 25 per

55. Para. 12(1)(0) of the Federal Act includes in income:

"any amount (other than an amount referred to in paragraph $18(1)(\mathrm{m})$. paid or payable by the taxpayer, or a prescribed amount) that became receivable in the year by virtue of an obligation imposed by statute or a contractual obligation substituted for an obligation imposed by statute by

(i) Her Majesty in right of Canada or a province.

(ii) an agent of Her Majesty in right of Canada or a province, or

(iii) a corporation, commission or association that is controlled, directly or indirectly in any manner whatever, by Her Majesty in right of Canada or a province or by an agent of Her Majesty in right of Canada or a province.

as a royalty, tax (other than a tax or portion thereof that may reasonably be considered to be a municipal or school tax). lease rental or bonus or as an amount, however described, that may reasonably be regarded as being in lieu of any such amount, and that may reasonably be regarded as being in relation to

(iv) the acquisition. development or ownership of a Canadian resource property, or

(v) the production in Canada

(A) of petroleum, natural gas or related hydrocarbons from a natural accumulation of petroleum or natural gas (other than a mineral resource) or from an oil or gas well.

(D) to any stage that is not beyond the crude oil stage or its equivalent. of petroleum or related hydrocarbons from tar sands from a mineral resource,

situated on property in Canada in which the taxpayer had an interest with respect to which the obligation imposed by statute or the contractual obligation, as the case may be, applied;".

56. Stipra n. 53; para. $18(1)(\mathrm{m})$ of the Federal Act denies a deduction in computing income in respect of:

"any amount (other than a prescribed amount) paid or payable by virtue of an obligation imposed by statute or a contractual obligation substituted for an obligation imposed by statute to

(i) Her majesty in right of Canada or a province.

(ii) an agent of Her Majesty in right of Canada or a province, or

(iii) a corporation, commission or association that is controlled, directly or indirectly in any manner whatever, by Her Majesty in right of Canada or a province or by an agent of Her Majesty in right of Canada or a province

as a royalty, tax (other than a tax or portion thereof that may reasonably be considered to be a municipal or school tax), lease rental or bonus or as an amount, however described, that may reasonably be regarded as being in lieu of any such amount, and that may reasonably be regarded as being in relation to

(iv) the acquisition, development or ownership of a Canadian resource property, or

(v) the production in Canada of

(A) petroleum, natural gas or related hydrocarbons from a natural accumulation of petroleum or natural gas in Canada (other than a mineral resource) or from an oil or gas well in Canada.

(D) petroleum or related hydrocarbons from tar sands from a mineral resource in Canada to any stage that is not beyond the crude oil stage or its equivalent;". 
cent of the taxpayer's income from production of oil and gas for the year. Taxpayers with liability for Crown royalty in excess of the amount of their resource allowance effectively find themselves "taxed" twice - once in the payment of the royalty and a further time in that the amount of the royalty was included in the income of the producer when it accrued to the Crown [in the case of the application paragraph $12(1)(0)$ ] or in that deductibility of an amount paid was denied so that taxable income was increased by the amount of the denied amount [as in the case of the application of paragraph $18(1)(\mathrm{m})]$.

The ARTC was introduced in part as a response to these measures as a non-taxable fiscal measure to reduce the impact of the federal initiative.

As noted above, the entitlement to ARTC is limited by the corporation's "maximum allowable credit" and by the "specified percentage" of Alberta Crown royalty. Both the "specified percentage" and the "maximum allowable credit" have been varied with the economic climate. ${ }^{57}$

TABLE 1

ALBERTA ROYALTY TAX CREDIT BY YEAR

$\begin{array}{cccc} & & \text { MAXIMUM } & \text { MAXIMUM } \\ \text { TAXATION YEARS } & \text { SPECIFIED } & \text { ALLOWABLE } & \text { ROYALTIES } \\ \text { BEGINNING }^{\prime} & \text { PERCENTAGE } & \text { CREDIT } & \text { AFFECTED }\end{array}$

Prior to

Aug. 31/81

50

$\$ 2.000,000$

$\$ 4,000,000$

Aug. $31 / 81$ and

ending before

Dec. 31/85

75

$4,000,000$

$5.333,333$

Jan. I/86 and

ending before

Mar. 31/86

50

$2,000,000$

$4,000,000$

Mar. 31/86 and

ending before

Jan. $1 / 88$

95

$3,000.000$

3.157 .895

Jan. $1 / 88$

75

$3,000,000$

$4,000.000$

Note to Table I:

1. Credit for taxation years ending after the period in which they began would be adjusted by pro-rating the maximum allowable credit for the year.

The ARTC was originally designed to assist small producers of oil and gas. This has affected the design of the program and has resulted in attendant and very complex limitations on the ability of particular parties to claim entitlement for the credit. Because of the ceiling placed in the form of the maximum allowable credit, a corporation having production revenue in excess of that which entitles it to the 
maximum allowable credit, will effectively pay a higher royalty on that incremental production. Taking 1984 as an example, a producer having $\$ 20,000,000$ in revenue and an effective royalty rate of 35 per cent would have paid Alberta Crown royalty in the amount of $\$ 7$ million. A royalty tax credit would be available equal to the lesser of 50 per cent of his Alberta Crown royalty ( $\$ 3.5$ million) and his maximum credit allowable for the year ( $\$ 2$ million). Therefore, he would be entitled to a credit of $\$ 2$ million and he would, in effect, be paying $\$ 2$ million in royalties on his first $\$ 11,428,570$ in production (a 17.5 per cent rate) and $\$ 3$ million on the $\$ 8,571,430$ balance (a 35 per cent rate).

The existence of a maximum allowable credit, therefore, resulted in a number of anomalies. In the first place, absent the existence of anti-avoidance rules, it would be more advantageous to produce oil and gas in a number of legally separate entities owned or controlled by the same parties, each of which would have its own ARTC. Indeed, because the normal form of business organization in the industry is the joint venture, there would be little added administrative complexity from such arrangements, subject to contractual arrangements with other members. As discussed further below, the Alberta Act has always had rules (the "association rules") designed to limit this means of multiplication of the credit and these rules have undergone substantial development and refinement.

The existence of the limit also meant that production would be more valuable in the hands of small producers than large producers. For example, a producer, absent limiting rules to the contrary, producing $\$ 100$ million worth of gas in 1984 , paying $\$ 40$ million (or 40 per cent) in royalties and having entitlement to $\$ 2$ million in ARTC, could sell interests in his production to a number of (for example,10) separate and unrelated entities. Each of these entities would be entitled to a $\$ 2,000,000$ credit which would be received annually free of tax. Assuming the economics of production remained the same, the same production could result in substantial increases in after tax cash flow (for example, of $\$ 18$ million) simply by a change of ownership. As will be discussed further, this incentive has been dealt with by the imposition of anti-avoidance rules.

Thirdly, the existence of the limit on ARTC makes it relatively more profitable for a small producer to develop and produce from lands than a large producer. This is less a problem or an anomaly resulting from the credit than it is the reason for its existence.

To avoid multiplication of the credit by mere multiplication of the number of corporate entities owning an interest in the property, the Alberta Act limits the maximum credit which is available to associated corporations. Section $26.1(4)$ of the Alberta Act provides:

If in a taxation year the corporation is an associated corporation, the corporation's maximum allowable credit is the amount allocated to the corporation under subsection (5) or (6).

Sections 26.1(5), (6) and (7) of the Alberta Act provide for associated corporations to file an agreement allocating the maximum allowable credit between themselves and for filing that agreement with the Provincial Treasurer. The maximum which can be allocated between the corporations in the aggregate is, in effect, the maximum allowable credit. If no agreement is filed, the Provincial Treasurer may allocate the credit between the corporations.

To determine whether two corporations are associated, the Alberta Act has adopted and expanded the association rules developed in the Federal Act to prevent 
multiplication of the small business deduction. ${ }^{58}$ These rules have been the subject of substantial discussion and commentary as well as a great deal of case law, and can and need only be reviewed very briefly here. Generally, two corporations will be associated with each other if, at any time in a taxation year: ${ }^{59}$

(a) one of the corporations controlled the other;

(b) both of the corporations were controlled by the same person or group of persons;

(c) each of the corporations was controlled by one person and the person who controlled one of the corporations was related to the person who controlled the other, and one of those persons owned directly or indirectly, in respect of each corporation, not less than 10 per cent of the issued shares of the capital stock thereof;

(d) one of the corporations was controlled by one person and that person was related to each member of a group of persons that controlled the other corporation, and that person or that group of persons owned directly or indirectly, in respect of each corporation, not less than 10 per cent of the issued shares of any class of the capital stock thereof;

(e) each of the corporations was controlled by a related group and each of the members of one of the related groups was related to all of the members of the other related group, and either of the related groups owned directly or indirectly, in respect of each corporation, not less than 10 per cent of the issued shares of the capital stock thereof.

The concept of "control" of a corporation is the subject of extensive case law and analysis, ${ }^{60}$ and the term "related" is defined under the Federal Act. ${ }^{61}$ These five basic rules are subject to several other interpretive provisions of the Federal Act which are adopted by the Alberta Act. Without further analysis, it can be said that the reason for this adoption is to prevent a corporation from duplicating or multiplying the credit by setting up or operating through subsidiary or sister corporations and transferring property engaging future activity to or through those separate entities.

Under certain circumstances, the Provincial Treasurer can also deem two otherwise unassociated corporations to be associated where: ${ }^{62}$

(a) their separate existence is not solely for the purpose of carrying out the business of the corporations in the most effective manner; and

(b) one of the main reasons for the separate existence of the corporations is to avoid one or more of those corporations becoming or remaining a "restricted corporation" (which will be discussed, infra).

In addition, under subsection 26.1(10) of the Alberta Act, the Provincial Treasurer may direct two or more corporations to be associated with each other if they have entered into one or more sales, exchanges, declarations of trust or other transactions that:

58. Supra n. $51 ; \mathrm{s}$. 1 of the Alberta Act provides that. with certain exceptions, each of the interpretations contained in Part XVII of the Federal Act apply for the purposes of the Alberta Act.

59. Supra n. 53, s. 256.

60. In general, one corporation will control another when it has such a number of votes as to allow it to elect the Board of Directors: Buckerfields Lid. v. MNR 64 D.T.C. 5301 (F.C.T.D.). Courts have recently expanded the concept of control to include circumstances where one corporation can effectively cause the winding-up of the other, even when it does not otherwise have voting control: The Queen v. Imperial General Properties [1985] 2 C.T.C. 299 (S.C.C.).

61. Supra n. 53, sub-ss. 25(2) to (6).

62. Id. sub-s. 26.1(9). 
(a) lack any substantial business purpose, other than increasing the aggregate amount of ARTC that may be claimed; or

(b) artificially increase the amount of royalty tax credit which may be claimed.

In addition to the association rules as expanded by the Alberta Act, there have been other anti-avoidance rules imposed to restrict multiplication of entitlement to ARTC through sale of a producing property owned by companies at the maximum allowable limit. Section 26.1 of the Alberta Act now generally provides that a corporation could not include, in computing its Alberta Crown royalty for a transaction year, amounts which were in respect of Crown royalties payable after August 31, 1982 in respect of a "restricted resource property". A restricted resource property was defined generally as a right or interest in any production from a well in Alberta with a finished drilling date on or before August 24, 1982, where the right or interest was owned by an "above-limit corporation" or "above-limit partnership" on August 24, 1982.63 An "above-limit corporation" was defined, inter alia, as one which would have had Alberta Crown royalty of \$5,333,333 in a taxation year ending August 31, 1982 (had it had a year end at that time), a corporation associated with such a corporation or a corporation deemed to be an above-limit corporation. ${ }^{6.4}$ This would have been sufficient Alberta Crown royalty to qualify the corporation for the maximum credit. An above-limit partnership was defined as a partnership in existence on August 24, 1982, each of the partners of which was an above-limit corporation on August 24, 1982.

As a result of this provision, it was no longer possible to increase royalty tax credits available in respect of a restricted resource property by selling it from a corporation receiving the maximum allowable credit to a company which could increase its credit.

However, an interest in production from wells with a finished drilling date of after August 24, 1982 was not defined as a restricted resource property, and the opportunity therefore existed for some multiplication. In addition, interests in wells owned by firms which increased their Alberta Crown royalty to $\$ 5,333,333$ after August 24, 1981, were unaffected.

The Province sought to remedy this in 1986 by expanding the definition of "restricted resource property" by adding to the definition, inter alia, production from a well which was disposed of by a "restricted corporation" or a "restricted partnership" after April 7, 1986. A restricted corporation was defined, inter alia, as one which, in its last taxation year, had Alberta Crown royalty in excess of $\$ 4,000,000$. A restricted partnership was a partnership having one or more restricted corporations as a member or members. For restricted resource properties acquired from restricted corporations, no Crown royalty was included in computing Alberta Crown royalty. For restricted resource properties acquired from a restricted partnership, the exclusion was effectively limited to the restricted corporation's interest in the partnership during the last fiscal period prior to its disposition of the restricted resource property. These rules substantially limit the ability to expand eligibility for the credit by sale of producing property.

The Alberta Act also contains a very broad anti-avoidance rule in subsection 26.1(8):

In computing the Alberta Crown royalty of a corporation, no amount shall be included that would, if included, artificially increase the Alberta Crown royalty of that corporation.

63. Id. para. $26(\mathrm{l})(\mathrm{h})$.

64. Id. para. $26(1)(a)$. 
In cases where specific and general anti-avoidance rules have not been sufficient to limit what the Province perceives to be unreasonable multiplication of the credit, the Province has apparently also resorted to common law and equitable remedies to attempt to limit availability of the credit. Among the causes of action apparently employed are unjust enrichment and civil conspiracy. ${ }^{65}$

Attempts to limit the credit might be criticized as preventing efficient reorganization and consolidation of corporate entities or of making such reorganizations unnecessarily awkward. If two non-associated corporations are approaching the maximum credit, for example, a reorganization which results in their becoming associated or converging into one entity, could result in substantial loss of value in the two entities. There may be substantial incentive to remain as an independent entity, which may be otherwise economically inefficient or to manipulate the technical rules (for example, exemptions for public companies) which result in awkward corporate structures. It is difficult to see, however, how the credit can be maintained in any form (other than an across-the-board royalty reduction) without limiting the ability of any one entity to claim the credit.

It is now proposed that the specified percentage be reduced to 50 per cent of Alberta Crown royalty and that the maximum allowable credit be $\$ 2$ million. ${ }^{66}$ There is some resistance to this from small producers. The benefit of the credit to such producers would, in some cases, be greater if a higher specified percentage and lower maximum allowable credit were implemented. For example, a producer having $\$ 4$ million in production and Alberta Crown royalty of $\$ 1$ million would be better off with an 80 per cent specified percentage and a $\$ 1,000,000$ maximum allowable credit than under current proposals.

The rules governing the ARTC are very complex and worthy of far more detailed examination. Even a brief discussion is relevant to an examination of the royalty structure, however, in that the effective royalty rate for some smaller producers is reduced by half by the existence of the credit. By reducing the variable cost of producing a cubic metre of natural gas to such producers, the ARTC can have the effect of making sales by them economic where such sales would not be economic by other producers. Whether this is responsible for recent discounting and the imposition of the AMP is not clear but could be worthy of further examination.

\section{SASKATCHEWAN}

\section{A. GAS ROYALTIES}

Natural gas royalties in Saskatchewan are reserved pursuant to the Petroleum and Natural Gas Regulations, 1969 which are made pursuant to the Crown Minerals Act. ${ }^{67}$ Section 14 of that statute provides that:

Except as otherwise provided in the regulations, every Crown lease shall except and reserve to the Crown a royalty or royalties on all Crown minerals that may be extracted, recovered or produced under that Crown lease.

The term "Crown mineral" is defined to include petroleum and natural gas found on or under any Crown mineral lands, which includes lands with respect to which the

65. Fryers, C.H., "New Approaches To Tax Litigation in the Province of Alberta" (unpublished, Canada Petroleum Tax Society 1986 Annual Conference, 15 May 1986).

66. Supra n. 25, "Royalty Review".

67. S.S. $1984-85$, c. 50-2. 
Crown has reserved mineral rights irrespective of its disposition of the surface rights. ${ }^{68}$ Section 15 of the Crown Minerals Act also provides that:

Every Crown lease may provide that the royalty or royalties excepted and reserved to the Crown thereunder shall be calculated and paid in the prescribed manner and at the prescribed rate or rates.

Section 59 of the Regulations prescribes the royalty rates applicable to Crown leases. ${ }^{69}$ As is the case with Alberta royalties, a distinction is drawn between "old gas" and "new gas". New gas is defined to mean all gas that is produced from a well that commenced production of gas after September 30, 1976; it also includes gas produced from wells producing before October 1, 1976 if the well had been previously abandoned and re-entry took place after September 30,1976 or the well was deepened to a new production zone after that date. However, new gas is defined to exclude any gas produced from units formed before October 1, 1976, gas which (in the opinion of the Minister) could have been produced from a well which first commenced production before October 1,1976 , as well as certain other gas. ${ }^{70}$ Old gas is defined as all gas which is produced from a gas well which is not new gas. ${ }^{71}$

The prescribed royalty excepted in respect of both old gas and new gas is determined in a three stage process. First, the appropriate Crown royalty rate is determined, and is expressed as a percentage of total monthly production for each category of gas produced from the well. For wells producing up to 115.4 thousand $\mathrm{m}^{3}$ of gas per month, the royalty rate is determined by the following formula:

$$
\mathrm{R}=\mathrm{MGP} \times \mathrm{Cg}
$$

where "MGP" is monthly gas production expressed in thousands of cubic metres produced or allocated to the well for the month and " $\mathrm{Cg}$ " is a factor specified in accordance with Schedule $G$ to the Petroleum and Natural Gas Regulations. ${ }^{72}$ For wells producing in excess of 115.4 thousand $\mathrm{m}^{3}$ per month, the royalty rate is determined in accordance with the following formula:

$$
\mathrm{R}=\mathrm{Kg}-\frac{\mathrm{Xg}}{\mathrm{MGP}}
$$

where "MGP" and " $\mathrm{Cg}$ " are defined as above and " $\mathrm{Kg}$ " and " $\mathrm{Xg}$ " are defined in Schedule $\mathrm{G}$ to the Regulations. ${ }^{73}$

The Province has now introduced a mechanism whereby these factors determine a royalty which is price sensitive. For new gas, the factor " $\mathrm{Kg}$ " will generally be determined in accordance with the following formula:

$$
\mathrm{Kg}=19.5+26 \underline{(\mathrm{P}-35)}
$$

where "P" is the average fieldgate price for gas as derived by the Department of Energy and Mines, expressed in dollars per thousand cubic metres. ${ }^{74}$ For example,

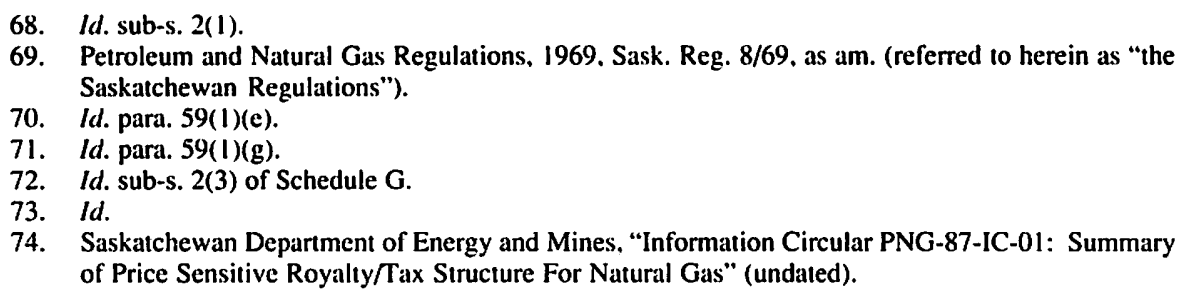

74. Saskatchewan Department of Energy and Mines, "Information Circular PNG-87-IC-01: Summary of Price Sensitive Royalty/Tax Structure For Natural Gas" (undated). 
where the average fieldgate price of gas is $\$ 66$ per thousand $\mathrm{m}^{3}$ (at which it has been set), the "Kg" factor in the royalty would be 31.71 .

For old gas, " $\mathrm{Kg}$ " is determined by the expression:

$$
\mathrm{Kg}=26+32.5 \frac{(\mathrm{P}-35)}{(\mathrm{P})}
$$

where "P" is average fieldgate price, determined as above. For an average field price of $\$ 66$ per thousand $\mathrm{m}^{3}$, the " $\mathrm{Kg}$ " factor is 41.27. . $^{75}$

The Department of Energy and Mines determines the "Cg" factor in terms of the "Kg" factor; it is simply the " $\mathrm{Kg}$ " factor divided by a constant, 230.76. In the above example, for new gas, "Cg" would be 0.1374 where the average fieldgate price for gas is $\$ 66$ per thousand $\mathrm{m}^{3}$. For old gas, the " $\mathrm{Cg}$ " factor would be 0.1788 . $^{76}$

The " $\mathrm{Cg}$ " factor is used to determine the royalty rate applicable to smaller wells (that is, those producing less than 115.4 thousand $\mathrm{m}^{3}$ per month). The actual percentage royalty relevant to any particular well is derived by multiplying the " $\mathrm{Cg}$ " factor by monthly gas production expressed in thousands of cubic metres. For example, were monthly gas production of new gas to be 10 thousand $\mathrm{m}^{3}$, the royalty rate would be 1.374 per cent. Were it to be 100 thousand $\mathrm{m}^{3}$, the rate would be 13.74 per cent. At the cut-off point for use of this formula, the percentage royalty is some 15.9 per cent. Similarly, monthly production of old gas of 10 thousand $\mathrm{m}^{3}$ would result in a 1.79 per cent royalty; production of 100 thousand $\mathrm{m}^{3}$ would result in a royalty of some 17.9 per cent and at the cut-off for application of this formula, the royalty would be some 20.6 per cent.

In order to determine the royalty rate for larger wells, the third factor, "Xg", must be determined. "Xg" is also a simple function of " $\mathrm{Kg}$ " and is determined by multiplying " $\mathrm{Kg}$ " by the factor 57.69 for both old and new gas. ${ }^{77}$

As noted above, the royalty rate for these larger wells is determined by the expression:

$$
\mathrm{Kg}-\frac{\mathrm{Xg}}{\mathrm{MGP}}
$$

This formula results in a royalty rate which mathematically approaches the " $\mathrm{Kg}$ " factor as monthly gas production increases. For example, where " $\mathrm{Kg}$ " is 31.71 (as for new gas with an average fieldgate price of $\$ 66.00$ per thousand $\mathrm{m}^{3}$, for wells producing 115.4 thousand $\mathrm{m}^{3}$ per month), the relevant royalty rate is 15.86 per cent; for wells producing twice that amount, the royalty rate would be 23.79 per cent. Similar production increases result in increases in the royalty rates for new gas.

Tables 2 and 3 illustrate the effect on the rate of royalty of a variation in average fieldgate prices and of monthly production for wells: 
TABLE 2

PERCENTAGE SASKATCHEWAN ROYALTY RATES

BY PRICE AND VOLUME

(Gross of Gas Cost Allowance)

(OLD GAS)

MONTHLY GAS

PRODUCTION

(THOUSAND Mi)
AVERAGE FIELD PRICE ( $\$$ PER THOUSAND $\mathrm{M}^{3}$ )

\begin{tabular}{rrrrr} 
& 56 & 66 & 76 & 86 \\
\cline { 2 - 5 } 60 & 9.9 & 10.7 & 11.3 & 11.8 \\
100 & 16.5 & 17.9 & 18.9 & 19.6 \\
115.4 & 19.1 & 20.6 & 21.8 & 22.6 \\
140 & 22.5 & 24.3 & 25.6 & 26.6 \\
180 & 25.9 & 28.0 & 29.6 & 30.8 \\
240 & 29.0 & 31.3 & 33.1 & 34.3
\end{tabular}

TABLE 3

PERCENTAGE SASKATCHEWAN ROYALTY RATES

BY PRICE AND VOLUME

(Gross Of Gas Cost Allowance)

(NEW GAS)

MONTHLY GAS

PRODUCTION

(THOUSAND $\mathrm{M}^{3}$ )
AVERAGE FIELD PRICE

( $\$$ PER THOUSAND $\mathrm{M}^{3}$ )

\begin{tabular}{rrrrr} 
& 56 & 66 & 76 & 86 \\
\cline { 2 - 5 } 60 & 7.6 & 8.2 & 8.7 & 9.1 \\
100 & 12.7 & 13.8 & 14.5 & 15.1 \\
115.4 & 14.6 & 15.9 & 16.8 & 17.5 \\
140 & 17.2 & 18.6 & 19.7 & 20.5 \\
180 & 19.9 & 21.5 & 22.8 & 23.7 \\
240 & 22.2 & 24.1 & 25.5 & 26.5
\end{tabular}

The second stage in determining the natural gas royalty in Saskatchewan is to apply the percentage royalty rates determined above to determine the Crown royalty share of each category of gas produced from or allocated to the well for the month. 
This is done by multiplying the Crown royalty rate by the total monthly production from each category. ${ }^{78}$

Finally, the actual royalty is determined by applying the Crown share to the wellhead value..$^{79}$ The wellhead value is itself determined by regulation generally as the contract price at the point of sale with allowances for a gas cost allowance (or a portion thereof if the point of sale is upstream from the fieldgate) and (where point of sale is downstream from the fieldgate) a cost of service factor. ${ }^{80}$

The amount of the gas cost allowance is determined from time to time by the Minister of Energy and Mines. ${ }^{81}$ In its present form, the amount of the allowance depends on whether the gas being sold is new gas or old gas. For old gas, the allowance is currently $\$ 5$ per thousand cubic metres; for new gas, it is $\$ 10$ per thousand cubic metres for gas sold at or downstream of the fieldgate. ${ }^{82}$ For gas sold upstream of the fieldgate, some portion of the allowance may be approved by the Minister. ${ }^{83}$ The gas cost allowance in Saskatchewan is deducted from the fieldgate price to determine the wellhead value. ${ }^{84}$ The royalty rate is then applied to the wellhead value to determine the Crown royalty. ${ }^{85}$

Cost of service is generally allowed on the basis of transmission costs payable; where carriers do not deal at arm's length or where transmission costs are considered by the Minister to be unreasonable, the Minister may establish the cost of service from time to time. ${ }^{86}$

The gas royalty regime in Saskatchewan is, then, price sensitive in that the royalty rate (as a percentage) increases with the price of gas. An increase in price, therefore, can have a twofold effect on the royalty paid - a higher rate (if the average price as determined by the Minister is increased) is applied to a higher price. The system is also production sensitive, in that different formulae govern the rates reserved in respect of smaller or lower producing wells.

\section{B. OIL ROYALTIES}

In computing oil royalties in Saskatchewan, a distinction is drawn between new oil, old oil and certain oil produced from enhanced recovery projects ("EOR oil"). New oil is oil which is not EOR oil and includes oil that is produced after 1986 from a well completed after 1973 and with a finished drilling date before 1987 outside existing pool boundaries, or inside pool boundaries, from deeper geological systems or structures or on an undrilled drainage unit established prior to $1974 .{ }^{87}$ It also includes oil produced from a well with a finished drilling date after 1986, oil approved by the Minister as new oil and a portion of oil produced from waterflood projects. ${ }^{88}$ Old oil is all oil which is not EOR oil or new oil. ${ }^{89}$ EOR oil generally

78. Supra n. 69, para. 59(4)(d).

79. Id. para. $59(4)(\mathrm{e})$.

80. Id. s. 60 .

81. Id. para. $59(1)(\mathrm{d})$.

82. Saskatchewan Department of Energy and Mines, "Implementation of Price Sensitive Royalty/Tax Structure for Saskatchewan Natural Gas Production" at 4 (20 October 1987).

83. Siupra n. 69. para. $59(2)(a)$.

84. Id.

85. Id. para. $59(3)(\mathrm{b})$.

86. Id. sub-para. $59(1)(a)(i)$.

87. Id. para. 57(e).

88. Id.

89. Id. para. $57(\mathrm{j})$. 
includes a portion of oil produced after 1986 from EOR projects, all oil from an EOR project in the Lloydminster heavy crude area or that is otherwise approved by the Minister. EOR projects are generally projects (other than waterflood projects) approved under the Oil and Gas Conservation Act which commenced operation after 1980 and which are designed to enhance total recovery of oil through thermal techniques or other techniques. ${ }^{90}$

As is the case with natural gas, determination of the Saskatchewan oil royalty is a three stage process. First, the appropriate Crown royalty rate, expressed as a percentage of total monthly production, is determined for the well and for the month in respect of each category of oil produced from or allocated to the well for the month. The rate (which is deemed to be at least one per cent) is determined by the following formula:

$$
\mathrm{R}=\mathrm{K}-\frac{\mathrm{X}}{\mathrm{MOP}}
$$

where "MOP" means monthly oil production in cubic metres, produced from or allocated to the well for the month. ${ }^{9}$ " $K$ " and " $X$ " are values specified in Schedule $F$ to the Petroleum and Natural Gas Regulations. As is the case with natural gas, the royalty factors are determined in accordance with a price sensitive formula. For new oil, the " $K$ " factor will be determined by the formula:

$$
\mathrm{K}=19.5+26 \frac{(\mathrm{PL}-50)}{(\mathrm{PL})}
$$

where "PL" represents the average wellhead price of non-heavy oil. ${ }^{92}$

For heavy new oil, the formula is:

$$
\mathrm{K}=13+19.5 \frac{(\mathrm{PH}-50)}{(\mathrm{PH})}
$$

where "PH" is the average wellhead price for heavy oil. All heavy oil (which is defined as oil produced from designated heavy oil areas) is classed as new oil.

The formula used in determining the " $\mathrm{K}$ " factor for old oil is the following:

$$
\mathrm{K}=26+32.5 \frac{(\mathrm{PL}-50)}{(\mathrm{PL})}
$$

where "PL" is defined as above. ${ }^{93}$

The " $\mathrm{X}$ " factor is simply a product of the " $\mathrm{K}$ " factor and a constant, 23.08.94

These formulae produce royalty rates which are sensitive to average wellhead prices and to production from particular wells. In general, as monthly oil production increases, the gross royalty rate will tend toward the " $K$ " factor.

Prices of $\$ 109$ per $^{3}$ for non-heavy crude oil and $\$ 67$ per $\mathrm{m}^{3}$ for heavy crude oil produced " $\mathrm{K}$ " factors of $43.59,33.57$ and 17.95 , for non-heavy old oil, non-heavy new oil and heavy oil, respectively. Very large production would result in these

90. Id. para. $57(\mathrm{~b})$.

91. Id. para. $58(\mathrm{l})(\mathrm{a})$.

92. Saskatchewan Energy and Mines, "Information Circular PNG-86-IC-O3, Revised: Summary of Price Sensitive Crude Oil Royalty Tax Structure and Marginal Well Royalty Tax Adjustment" (undated).

93. Id.

94. Id. 
factors effectively being the royalty factors. For example, production of 10 thousand $\mathrm{m}^{3}$ per month would result in royalty rates of 17.91 per cent for heavy oil, 33.49 per cent for non-heavy new crude oil, and 43.49 per cent for non-heavy old crude oil. However, production of $200 \mathrm{~m}^{3}$ per month would result in reduced royalty rates of 15.88 per cent, 29.7 per cent and 38.56 per cent, respectively.

As is the case with the Alberta royalty, the royalty rate is sensitive to variations in price. For example, a price of $\$ 109$ for heavy crude will result in a " $\mathrm{K}$ " factor of 33.57 for non-heavy old oil. For a price of $\$ 163.50$ (50 per cent higher), the " $\mathrm{K}$ " factor would be 37.54 per cent. This, of course, understates the effect on the royalty which is collected. If the price factor reflects the price paid to the producer, the actual royalty would increase by almost 68 per cent as a result of a 50 per cent increase in price.

\section{SASKATCHEWAN BUDGET}

In the 1988-89 Budget for the Province of Saskatchewan, it was announced that certain tax initiatives would be introduced which would affect the taxation of resource corporations and which would provide credits under certain circumstances to such corporations in respect of their Saskatchewan resource sales. These are relevant to a discussion on royalties because they are imposed with respect to the value of production.

The most important of these would be the Corporation Capital Tax Surcharge. This surcharge is intended to be $2 \%$ of the difference between the corporation's "value of Saskatchewan resource sales" and its existing "Corporation Capital Tax" liability. The corporation capital tax in its present form allows a corporation to deduct deferred exploration and development expenses in the computation of its paid-up capital. As a result, corporations which have substantial paid-up capital but which have deferred exploration and development expenses in substantial amounts would often have no corporation capital tax liability. Accordingly, effective July 1, 1988, large resource corporations will be assessed a Corporation Capital Tax Surcharge equal to the difference between their existing corporation capital tax liability and $2 \%$ of the corporation's value of Saskatchewan resource sales. The tax only applies to large corporations, because there is no tax exigible with respect to corporations which have paid-up capital of less than $\$ 10,000,000 .^{95}$

The value of Saskatchewan resource sales will be defined to include, in the case of Crown gas, the wellhead value of the Crown gas as determined pursuant to section 59(2) of the Saskatchewan Regulations multiplied by the total monthly production of the Crown gas. A similar charge is exigible in respect of freehold gas under the Freehold Oil and Gas Production Tax Regulations. In the case of oil, the value of resource sales will be computed as the wellhead value of the Crown oil (as determined pursuant to the Saskatchewan Regulations) multiplied by the total monthly production of Crown oil. ${ }^{96}$

Somewhat balancing the new capital tax is the Saskatchewan Resource Credit ("SRC") which can be used to offset Crown royalties. The SRC will be equal to one per cent of the value of Saskatchewan resource sales. The SRC would appear to be computed on a well by well basis. A well in respect of which a royalty of less than

95. Saskatchewan Finance and Saskatchewan Energy and Mines. "Information Circular: $1988-89$ Saskatchewan Tax Initiatives" (15 April 1988).

96. Id. at 5: Freehold Oil and Gas Production Tax Regulations, Sask. Reg. II/83. as am. 
one per cent is imposed will never have a royalty rate of less than zero, and wells which enjoy a royalty holiday will not benefit from the credit. Absent these circumstances, the credit would have a value of one per cent of Saskatchewan resource sales in the aggregate. ${ }^{97}$

For smaller corporations operating in the Province of Saskatchewan, the net effect of these initiatives would appear to be positive. For larger corporations, there will generally be an increase of about one per cent of the value of Saskatchewan resource sales payable in additional tax. ${ }^{98}$

\section{BRITISH COLUMBIA}

Oil and gas royalties in British Columbia are reserved pursuant to sections 91 and 92 of the Petroleum and Natural Gas $\mathrm{Act}^{\text {99}}$ and the Petroleum and Natural Gas Royalty Regulations. ${ }^{100}$

\section{A. GAS ROYALTIES}

Natural gas royalties in British Columbia are currently undergoing review, with intended revision effective June 1, 1988.

Natural gas royalty rates in respect of non-associated gas as currently designed are sensitive to a number of factors, including age of the well (older wells have higher royalty rates), location, depth (deeper wells have lower rates) and production (high production wells pay a higher rate). ${ }^{101}$ Every well is categorized with respect to the four factors, and a royalty rate is determined as the sum of the applicable rates. A minimum royalty rate of $14 \%$ is imposed. To the rate thus determined, a "rate adjustment factor" is applied to determine an "effective royalty rate". For example, the basic rate (to which an adjustment factor would be applied) for a 5 year old well, 2000 metres deep (8 percentage points of royalty), producing 600 thousand $\mathrm{m}^{3}$ ( 2 percentage points of royalty), located in Area $\mathrm{D}$ (4 percentage points of royalty), would be 20 per cent. To that would be applied the royalty rate adjustment factor which would be determined by the value of gas. For gas selling for $\$ 71.50$ per thousand $\mathrm{m}^{3}$, the adjustment factor would be 0.61 and the royalty rate reduced to 12.2 per cent. ${ }^{102}$ The rate for associated gas is 22.5 per cent multiplied by the same adjustment factor. ${ }^{103}$

British Columbia also allows for certain costs to be deducted in computation of royalties. Section 5(10) of the B.C. Regulations provides that a producer may deduct from the actual value or fixed selling price of the natural gas sold, tariffs charged by contract carriers for transporting and by contract processors for processing the natural gas sold (except where the tariff is used to determine the actual value or fixed selling price of the gas). Allowances may also be established with respect to main field gathering and dehydration systems, field compression and conservation of associated gas. ${ }^{104}$ In addition, there is an allowance akin to Alberta's gas cost allowance in respect of gas processing plants owned and operated by the operator for

97. Supra n. 95 at 6.

98. Id.

99. R.S.B.C. 1979 , c. 323, as am.

100. B.C. Reg. 200/85, as am. (referred to herein as "the B.C. Regulations"),

101. Id. s. 4.

102. Id. Tables 1 and 2.

103. Id. s. 4.

104 ld. sub-s. 5(10). 
his own use. Where a fee is paid to an operator in order to use the operator's facilities to process gas, an allowance is also available. ${ }^{105}$ In general, this allowance differs from Alberta's in that the cost per unit is determined by dividing aggregate cost by plant capacity rather than by throughput. ${ }^{106}$

It is likely that the existing system in British Columbia will be radically changed effective June 1, 1988. At the time of writing in May 1988, the proposal is to replace the present system with one which is "more compatible with a deregulated petroleum and natural gas environment". ${ }^{107}$ In place of the five-component formula currently used, which determines the gross royalty rate on the basis of depth, age, area and production rate, and an effective rate by the application of a price factor, it is now proposed that a formula in the same format as the Alberta formula be used. ${ }^{108}$ It is suggested that for non-associated gas, a 15 per cent base royalty be imposed when prices are below $\$ 50.00$ per thousand cubic metres. For prices in excess of that, the following royalty is proposed:

$$
\mathrm{R} \%=\frac{750+25(\mathrm{P}-50)}{\mathrm{P}}
$$

where "R\%" is the royalty rate and "P" is the price for gas. Use of this formula would result in a theoretical maximum royalty rate of 25 per cent. ${ }^{109}$ At a price of $\$ 71.00$ per thousand $\mathrm{m}^{3}$, the royalty rate is in the order of 18 per cent, compared to 27 per cent in Alberta (both rates gross of gas cost allowance). On "conservation" gas (that is, associated gas), it is proposed that an 8 per cent royalty be imposed, with a price sensitive royalty being implied for prices in excess of $\$ 50.00$ per thousand $\mathrm{m}^{3} .{ }^{110}$ Such rates would approach 15 per cent, with the rate at $\$ 71.00$ being slightly in excess of 10 per cent.

By removing "age" as a factor in determining the royalty rate, there would no longer be any distinction between old and new gas. The rate is no longer to be sensitive to production rate: low producibility wells and wells which otherwise have low production rates pay the same royalties, ceteris paribus, as high production wells. No distinction is to be drawn in computation of the royalty rates themselves between different geographic areas.

It is also proposed that producer cost of service allowances be amended. It is proposed that the allowance differentiate only two (rather than four) areas. ${ }^{\prime \prime \prime}$ It is also proposed that the allowance be higher for gas with hydrogen sulphide (" $\mathrm{H}_{2} \mathrm{~S}$ ") in excess of one per cent. The proposed allowances are set out in Table 4 below: ${ }^{112}$

105. Id. para. $5(10)(\mathrm{c})$.

106. Discussions with officials of the Department of Energy and Mines in the Spring of 1988.

107. Government of British Columbia, “Information Letter F88-2: New Crown Royalty Regime for Natural Gas and Natural Gas By-Products" (11 May 1988).

108. Id.

109. Id.

110. Id.

111. Id.

112. Id. 
TABLE 4

PROPOSED BRITISH COLUMBIA

COST OF SERVICE ALLOWANCES

( $\$$ PER THOUSAND $\mathrm{M}^{3}$ )

\begin{tabular}{lcccccc} 
& \multicolumn{2}{c}{ AREA $\mathrm{D}$} & & \multicolumn{2}{c}{ ALL OTHER AREAS } \\
ALLOWANCE & $\mathrm{H}_{2} \mathrm{~S}<1 \%$ & $\mathrm{H}_{2} \mathrm{~S}>1 \%$ & & $\mathrm{H}_{2} \mathrm{~S}<1 \%$ & $\mathrm{H}_{2} \mathrm{~S}>1 \%$ \\
\cline { 2 - 3 } \cline { 5 - 6 } $\begin{array}{l}\text { Gas Gathering } \\
\text { and Rehydration }\end{array}$ & 5.00 & 11.00 & & 4.00 & 5.00 \\
Field Compression & 8.00 & 9.00 & & 5.00 & 5.00 \\
Gas Conservation & 16.00 & 16.00 & & 16.00 & 16.00
\end{tabular}

It is also proposed that the "site specific" gas cost allowance be calculated on the basis of plant throughput rather than capacity. At the present time, the allowance in respect of producer-owned facilities which operate at less than full capacity is lower than it would be if the allowance were allocated only on the basis of throughput.

From the standpoint of the Province, the proposed system is perceived to have advantages in being a simpler formula to administer and the added advantage of distinguishing between conservation gas and other gas and between acid gas and other gas. The objective of the changes is to "simplify both industry's and government's administrative procedures while minimizing the effect on total royalties collected by the Province under the present regime". ${ }^{113}$

\section{B. OIL ROYALTIES}

As is the case with Alberta and Saskatchewan, a distinction is drawn between "new oil" and "old oil". New oil is generally oil from pools which did not contain a well completed prior to November 1, 1975, but includes, inter alia, certain incremental oil and wells from which oil had not been produced for three consecutive years. ${ }^{114}$ Old oil means all oil which is not classified as new oil. ${ }^{115}$ Certain oil (such as discovery oil, "cost" oil and oil from certain tertiary production pilot projects) is exempt from royalty. ${ }^{116}$

Royalty rates for old and new oil are production sensitive, with the degree of production sensitivity being greater for smaller pools. The old oil royalty is generally:

$$
\mathrm{R} \%=\frac{(11.4+.4(\text { Production }-95)) \times 100}{\text { Production }}
$$

where "R\%" is the percentage royalty and "production" is measured in cubic metres per month. ${ }^{117}$ A royalty of $37.3 \%$ would result from production of $1000 \mathrm{~m}^{3}$ per month; production of half that would result in a royalty rate of about $34.7 \%$. The minimum possible royalty is 12 per cent and the theoretical maximum is 40 per cent.

113. Id.

114. Supra n. 100, s. 1.

115. Id.

116. Id.

117. Id. s. 3, item 2 . 
For old oil from wells producing less than $95 \mathrm{~m}^{3}$ per month, the royalty rate is very production sensitive. The royalty formula is:

$$
\mathrm{R} \%=\frac{(\text { Production })^{2} \times 100}{792 \times \text { Production }}
$$

with terms defined as above. ${ }^{118}$ Production of $20 \mathrm{~m}^{3}$ results in a royalty rate of 2.5 per cent. Production of $95 \mathrm{~m}^{3}$ results in a 12 per cent royalty rate.

New oil royalty rates are generally determined by the formula:

$$
\mathrm{R} \%=\frac{(23.9+.3(\text { Production }-159)) \times 100}{\text { Production }}
$$

where " $\mathrm{R} \%$ " and "Production" are defined as above. Royalty rates range from approximately 15 per cent to a theoretical maximum of 30 per cent. ${ }^{120}$ For oil from spacing areas producing less than $159 \mathrm{~m}^{3}$ per month, royalty rates are determined by a formula similar to that for old oil from smaller pools and range from zero to about 15 per cent.

Oil royalties in British Columbia are not price sensitive. There is no "adjustment factor" as exists for gas.

\section{CONCLUSION}

In establishing a royalty, or any tax, there are goals which may be considered. A royalty set with respect to any particular source of production, first of all, should generate revenue. If the rate is set too high and production from that source does not take place, the royalty has failed as a revenue-generating device irrespective of what other theoretical merits it may have.

A royalty should be designed to capture only "economic rent" associated with production: that is, the revenue generated over and above the cost of production and any return needed to attract capital. Capturing revenue which does not consider production costs may discourage production; from the Crown fiscal standpoint, a royalty structure which does not respond to higher revenues may not capture a sufficient share of increases in value. As a result, some price and cost sensitivity is desirable. A publicly-imposed royalty on oil and gas production might also be structured with a conservation goal in mind, so that its imposition does not cause a disincentive to produce marginal properties. In addition, as with any tax, a royalty scheme should be relatively simple to administer, given the amount of money involved, and relatively equitable, given the complex of other factors which should be considered.

Each of Alberta, Saskatchewan and British Columbia have established sophisticated mechanisms to determine the applicable royalty reserved in respect of petroleum and natural gas reserved to the Crown. In different ways, the three provinces have attempted to make the royalties sensitive to the profitability of production. For this reason, royalty systems differentiate between small wells and larger wells, presumably on the basis that smaller wells generate less income per unit produced. A high fixed royalty rate in respect of such a well or unit might result in it being uneconomic to produce, with the result that both conservation and fiscal goals may

118. Id. s. 3, item 1 .

119. Id. s. 3, item 4 .

120. Id. s. 3, item 3 . 
be sacrificed. Each province (until recently, in the case of British Columbia) has ensured that the royalty rate applicable to smaller wells or units is lower than for larger wells.

With the exception of British Columbia's oil royalties, each of the provinces has also attempted to establish royalties which are sensitive to the price of the product taxed. The reasoning, one can assume, is the same: too high a fixed royalty at too low a price may result in less oil being produced at marginal wells and less revenue being generated. At the same time, when prices rise, a price sensitive royalty system can capture a greater share of the "economic rent" associated with the production of the resources. While the degree of price sensitivity may appear small, an increase in a royalty rate from, for example, 30 to 33 per cent, increases the Crown's share by 10 per cent, and may have a significant fiscal impact. The same flexibility results in the province sharing the burden of falling prices.

The distinction between new and old oil and gas can be viewed as arising on several grounds. In one sense, the lower royalty reserved in respect of new product can be viewed as an incentive. Perhaps more realistically, one can view the measure as an attempt to capture more of the economic rent associated with production from old oil pools which are likely to be produced irrespective of the royalty rate.

As noted above, British Columbia is in the process of abandoning the age and depth of a well as factors in determining royalty rates in a move toward administrative simplicity. Administrative simplicity would seem to govern the Saskatchewan gas cost allowance and the proposed move in Alberta for determining that allowance on a "functional plant basis".

Administrative simplicity is less apparent as a goal in the ARTC program. The need to restrain multiplication of the credit by creation of new entities or sale of producing properties has resulted in an extremely complex set of rules to govern eligibility for the credit and to determine the maximum allowable credit for a given person. It is difficult to see, however, how a program with the goal of assisting small producers could be much less complex. If there was no maximum allowable credit, royalty rates would effectively be halved. If there were no limits set by the association rules, all production would eventually be governed by blocks of small associated corporations. If there was no restriction on sale of production, the economics of the ARTC would eventually dictate that most producing property would be acquired by small producers from large producers. The central question to be asked in respect of that program is whether a program to assist small producers should exist at the expense of higher overall royalty rates, assuming constant fiscal objectives for the Province. This is a matter of economic, social and political policy and Alberta, to date, has chosen to maintain a policy which appears to promote a large independent and deconcentrated segment of the industry.

It would appear, then, that many of the considerations which should or could govern royalty rates have been considered explicitly or implicitly in structuring the system of Crown royalties. The balance chosen between competing goals differs between provinces, and recent changes, proposed and implemented, show how that balance can evolve with time and circumstances. 